Dorling, D. (2016) France shows what has gone wrong in the UK and US, BMJ 2016; 355 doi:

http://dx.doi.org/10.1136/bmj.i6520 (Published 08 December) Cite this as: BMJ 2016;355:16520

Toll free: http://bmj.com/cgi/content/full/bmj.i6520?ijkey=QY6i8hS8kaIgttF\&keytype=ref

\title{
France shows what has gone wrong in the UK and US
}

\author{
Danny Dorling, professor of geography \\ School of Geography and the Environment, Oxford \\ University, Oxford , UK
}

The outcome of the French presidential election, in which the Republican Francois Fillon, Front National's Marine Le Pen, and the Socialist Party will be vying for position in April 2017, could have wide reaching implications for public health in Europe. Concerns over living standards in France will influence the votecould income inequality and poor health also influence voting, as it seems to have done in the UK referendum and the US presidential election? Marine Le Pen has already argued that Donald Trump's victory in the US is a precursor to her own impending success. ${ }^{1}$

The strongest predictor of a rise in Republican voting for Donald Trump was a decline in the health of the residents in their local area. An age adjusted index showing falls in local life expectancy, obesity, and diabetes-as well as heavy drinking and lack of regular physical activity-best predicted those areas that swung the most to Trump. 2 
Donald Trump repeatedly cited the UK Brexit vote as a precedent, suggesting that he could win "Brexit times ten."3 In the UK, self reported health has fallen each year since 2010, and in the year to June 2015, UK death rates rose for all age groups apart from people aged 25-29 and younger than 10.4 Public health spending was a key issue in both the Brexit debate ${ }^{\mathbf{5}}$ and the US presidential election. ${ }^{6}$ In the UK, Leave voters were more likely than Remain voters to believe that wealth was unfairly distributed, especially those on lower incomes. 7

However, France is different. By 2020 France is set to spend $54 \%$ of its gross domestic product on public services, compared with $36 \%$ in the UK and $35 \%$ in the US (fig $1 \Downarrow$ ). 8

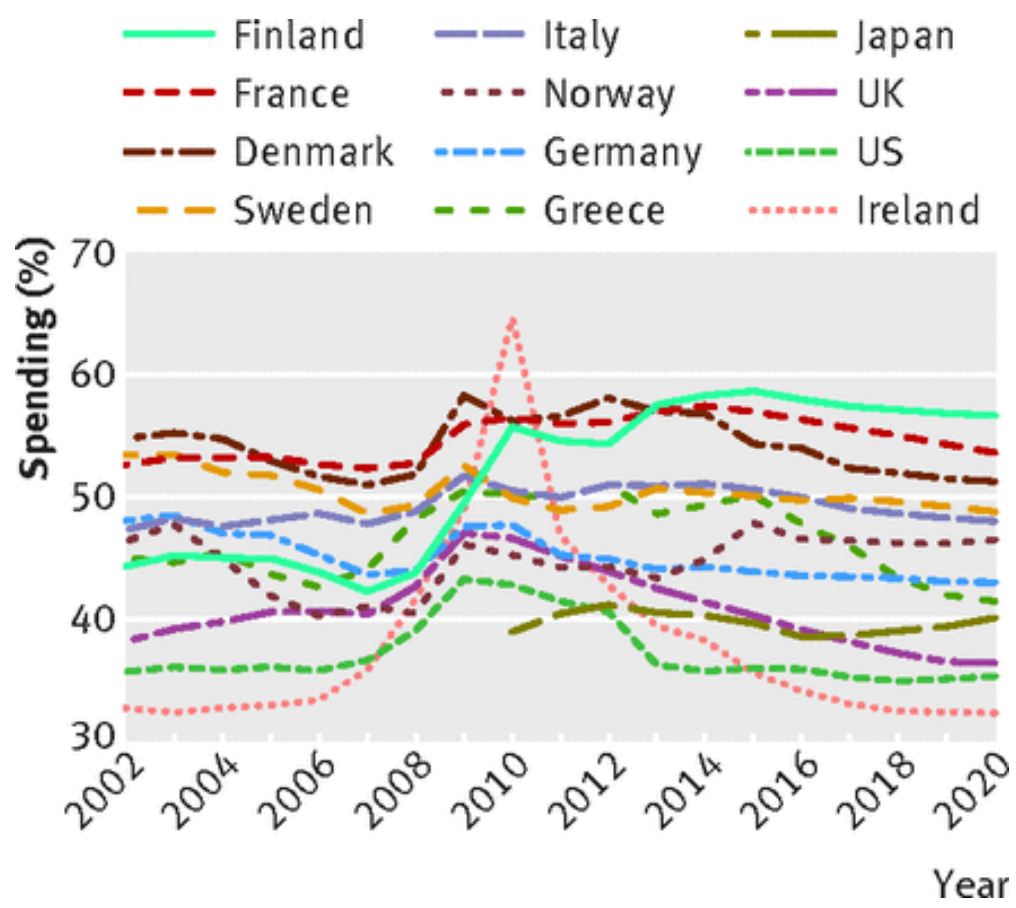

Fig 1 State spending as a proportion of GDP for 12 rich countries (data points after 2014 are projections) 89 
In 2015, the Organisation for Economic Cooperation and Development (OECD) identified the US and UK as two of the most unequal affluent countries in the world in its database of 34 countries. ${ }^{10}$ The US ranked fourth, behind Chile, Mexico, and Turkey, and the UK sixth, with Israel in fifth place. By contrast, income inequality in France is below the average for all OECD countries combined. This is because the richest French citizens take a much smaller proportion of their country's total income compared with those in the US or the UK.

The Paris School of Economics has maintained the World Wealth and Income database since 2011.11 The most extensive and consistent dataset of the world's best paid individuals constructed from tax records, it shows that in 2007-the year before the current financial crisis began - the highest remunerated $1 \%$ of people paying taxes in the US took $18.3 \%$ of all available income in that country (or $23.5 \%$ if capital gains-non-employment income-are included), and in the UK they took 15.4\%. In France, the same group took just $9.1 \%$ of all available income.

The World Bank reports that since 1960, life expectancy has risen by nine years (to 79 years) in the US, by 10 years (to 81 ) in the UK, and by 12 years (to 82) in France. 12 In France income inequalities are lower than they were in 1960, when their highest paid $1 \%$ took $9.7 \%$ of all income and France was more unequal than both the US and the UK. 
Today, France is a far more equitable country than either the US or the UK. Its people are more productive, and the country spends more on public services, including health, which has improved faster than in the UK or US. But in 2015, deaths in France rose by more than 40000 compared with the year before, and during the June heatwave that year, "thousands of patients waited on stretchers."13

Right wing politicians in France will try to paint the country as a failed state in need of drastic reform in the weeks to come. In reality, France shows how the UK and US have gone wrong.

France is no utopia, but compared with the UK, it has six more doctors to treat every 10000 patients (21\% more per person), 35 more hospital beds per 10000 people (130\% more per person), and people stay in hospital for less time on average (5.6 days instead of 6.9 days). ${ }^{14}$ The productivity of those in work is higher, partly because health is better and people are not forced into low paid employment. 15 There is a clear and present danger that leading French politicians will seek to portray their country as a failing state in the race for votes this year. But if that can be avoided then we should not assume that the inequality and poor health that helped get Brexit over the line and Trump into power will necessarily play out that way in France. Facts, and how they are presented, will matter more than ever before. 


\section{Footnotes}

Competing interests: I have read and understood BMJ policy on declaration of interests and have no relevant interests to declare. Provenance and peer review: Commissioned, not externally peer reviewed.

\section{References}

$1 . \quad 4$ Dearden L. Marine Le Pen's Front National issues chilling warning over Donald Trump win: "Their world is collapsing. Ours is being built." Independent 2016 Nov 9. http://www.independent.co.uk/news/world/americas/uselections/donald-trump-president-us-election-result-frontnational-marine-le-pen-jean-marie-far-right-worlda7406426.html

2. $\leftarrow$ Local health outcomes predict Trumpward swings. Economist 2016 Nov 19. http://www.economist.com/news/united-states/21710265local-health-outcomes-predict-trumpward-swings-illnessindicator

3. $\triangleleft$ Ferguson N. Donald Trump's American Brexit. Boston Globe 2016 Nov 7. https://www.bostonglobe.com/opinion/2016/11/07/trumpamerican-brexit/9I5kes4FszzhbxRdmMjTBN/story.html

4. 4 Dorling D. Public health was declining rapidly before the Brexit vote. Public Sector Focus 2016 Jul/Aug:202. http://www.dannydorling.org/?page_id=5639

5. 4 Eight reasons Leave won the UK's referendum on the EU. BBC News 2016 Jun 23. http://www.bbc.co.uk/news/uk-politics-eu-referendum36574526

6.

$\triangleleft$ Goldstein A. Obamacare's future in critical condition after Trump's victory. Washington Post 2016 Nov 9. https://www.washingtonpost.com/national/healthscience/acas-future-in-critical-condition-with-trumpsvictory/2016/11/09/7c5587e8-a684-11e6-ba59a7d93165c6d4_story.html 
7.

$\triangleleft$ Wright D, Case R. Leave voters felt ignored and left behind as post-Brexit poll reveals extent of economic division across UK. Joseph Rowntree Foundation $2016 \mathrm{Jul}$ 15. https://www.jrf.org.uk/press/leave-voters-felt-ignoredand-left-behind-brexit-poll

8. $\triangleleft$ Dorling D. A better politics: how government can make us happier. LPP, 2016. http://www.dannydorling.org/books/betterpolitics/material/figu re-2.html

9. outlook database.

$\triangleleft$ International Monetary Fund. World economic https://www.imf.org/external/pubs/ft/weo/2016/02/weodata/in dex.aspx

10. $\triangleleft$ Organisation for Economic Cooperation and Development. In it together: why less inequality benefits all. OECD, 2015. http://www.oecd.org/social/in-it-togetherwhy-less-inequality-benefits-all-9789264235120-en.htm

11. $\triangleleft$ Alvaredo F, Atkinson T, Piketty T, Saez E, Zucman G. The world wealth and income database. http://www.wid.world

12. $\triangleleft$ World Bank. Life expectancy at birth, total (years). 1960-2014. http://data.worldbank.org/indicator/SP.DYN.LE00.IN

13.

4 Gee O. Why has life expectancy in France taken a historic drop? The Local 2016 Jan 19.

http://www.thelocal.fr/20160119/wild-weather-sees-franceslife-expectancy-drop

14. $\triangleleft$ NHS Confederation. Key statistics on the NHS. Nov 2016. http://www.nhsconfed.org/resources/keystatistics-on-the-nhs

15.

$\triangleleft$ Szreter S, Kinmouth AL, Kriznik N, Kelly MP. Health, welfare, and the state-the dangers of forgetting history. Lancet 2016;388:2734 doi:10.1016/S0140-6736(16)32429-1. 